
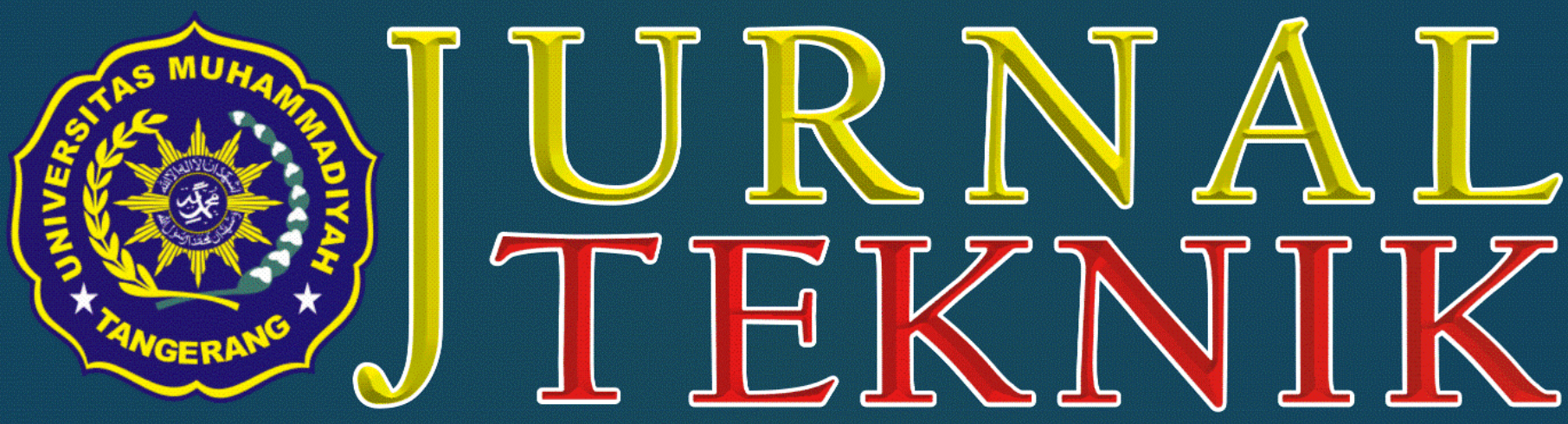

TEKNIK INFORMATIKA - TEKNIK MESIN - TEKNIK SIPIL - TEKNIK ELEKTRO - TEKNIK INDUSTRI

PENGGUNAAN METODE POQ (PERIODE ORDER QUANTITY) DALAM UPAYA PENGENDALIAN TINGKAT PERSEDIAAN BAHAN BAKU (HDN)

(STUDI KASUS PADA PERUSAHAAN FRAGRANCE DI TANGERANG) Diah Septiyana

OPTIMASI PENGENDALIAN BANJIR DI KOTA TANGERANG DENGAN METODE GOAL PROGRAMMING DAN AHP (ANALYTICAL HIERARCHY PROCESS)

Shiddiq Waluyo \& Saiful Haq

ANALISA TATA LETAK MATERIAL DI GUDANG PT GGS DALAM MENINGKATKAN EFEKTIFITAS KERJA

Ellysa Kusuma Laksanawati \& Rahman Ridho

STUDI EKSPERIMENTAL PENGUJIAN KEKASARAN PERMUKAAN DAN KEAKURASIAN DIMENSI PADA PROSES DRY MACHINING BAJA AISI 01 Riki Candra Putra

ANALISA TINGKAT PENERIMAAN PELANGGAN SELULAR TERHADAP LAYANAN SELULAR BERBASIS 3G PADA PELAJAR SMP DI KABUPATEN TANGERANG Triyono
ANALISIS KELAYAKAN PROYEK

PEMBANGKIT LISTRIK TENAGA MINIHIDRO

(PLTM) MENGGUNAKAN SOFTWARE RETCSREEN (STUDI KASUS PADA PLTM SIMALUNGUN, SUMATERA UTARA)

Ria Rossaty

KAPASITAS MOMEN DAN GESER PADA STRUKTUR BALOK DI BANGUNAN TINGGI WILAYAH RAWAN GEMPA

Almufid

MODEL LAYANAN INFORMASI LOKASI MASJID DI WILAYAH KOTA TANGERANG MENGGUNAKAN PERANGKAT BERGERAK (MOBILE DEVICE)

Angga Aditya Permana

ANALISA GANGGUAN HUBUNG SINGKAT

DENGAN MENGGUNAKAN ETAP 12.6.0

PADA PT $X$

Badaruddin \& Mochamad Isnan Arsyad

ANALISIS STRATEGI PEMASARAN OBAT BATUK PROSPAN DENGAN MENGGUNAKAN METODE SWOT PADA PT. SOHO GLOBAL HEALTH

Hermanto \& Ahmad Rizki K.

MEMBANGUN VOICE OVER INTERNET PROTOCOL (VOIP) MENGGUNAKAN SOFTWARE ASTERISK

Bambang Adi Mulyani

\title{
Diterbitkan Oleh:
}

Fakultas Teknik Universitas Muhammadiyah Tangerang Jl. Perintis Kemerdekaan I No. 33, Cikokol Tangerang - TIp. 021 - 51374916

\begin{tabular}{|c|c|c|c|c|c|}
\hline Jurnal & Vol. & No. & HIm. & FT. UMT & ISSN \\
\cline { 2 - 6 } & 5 & 1 & $1-94$ & Mei 2016 & $2302-8734$ \\
\hline
\end{tabular}




\section{J U R N A L TEKN I K}

Teknik Informatika $\sim$ Teknik Mesin $\sim$ Teknik Sipil Teknik Elektro Teknik Industri

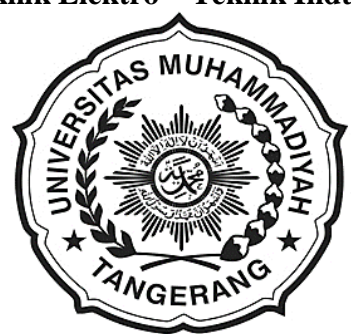

FAKULTAS TEKNIK UNIVERSITAS MUHAMMADIYAH TANGERANG

Pelindung:

Dr. H. Achmad Badawi, S.Pd., SE., MM

(Rektor Universitas Muhammadiyah Tangerang)

Penanggung Jawab:

Ir. Saiful Haq, M.Si.

(Dekan Fakultas Teknik)

Pembina Redaksi:

Rohmat Taufik, ST., M.Kom.

Drs. H. Syamsul Bahri, MSi.

Drs. Ir. Sumardi Sadi, MT.

Pimpinan Redaksi:

Drs. Ir. Sumardi Sadi, MT

Redaktur Pelaksana:

Yafid Efendi, ST, MT.

Editor Jurnal Teknik UMT:

Drs. Ir. Sumardi Sadi, MT.

Dewan Redaksi:

Hendra Harsanta, SPd., MT.

Tri Widodo, ST.,MT.

Bambang Suhardi W, ST., MT.

Almufid, ST., MT.

Siti Abadiah, ST., MT.

M. Jonni, SKom., MKom.

Elfa Fitria, SKom, MKom.

Lenni, ST., MT.

Kasubag:

Ferry Hermawan, MM.

Keuangan:

Elya Kumalasari, S.Ikom.

Setting \& Lay Out:

Muhlis, S.E

Saiful Alam, SE.

Mitra Bestari:

Prof. Dr. Aris Gumilar

Ir. Doddy Hermiyono, DEA.

Ir. Bayu Purnomo

Dr. Ir. Budiyanto, MT.

J U R N A L T E K N I K

Diterbitkan Oleh:

Fakultas Teknik Universitas Muhammadiyah Tangerang

Alamat Redaksi:

Jl. Perintis Kemerdekaan I No. 33, Cikokol Tangerang Tlp. (021) 51374916

\begin{tabular}{|c|c|c|c|c|c|}
\hline Jurnal & Vol. & No. & Hlm. & UMT & ISSN \\
\cline { 2 - 6 } Teknik & 5 & 1 & $1-94$ & Mei 2016 & $2302-8734$ \\
\hline
\end{tabular}

\section{DAFTAR ISI}

- PENGGUNAAN METODE POQ (PERIODE ORDER QUANTITY) DALAM UPAYA PENGENDALIAN TINGKAT PERSEDIAAN BAHAN BAKU (HDN) (STUDI KASUS PADA PERUSAHAAN FRAGRANCE DI TANGERANG) - 1 Diah Septiyana

- OPTIMASI PENGENDALIAN BANJIR DI KOTA TANGERANG DENGAN METODE GOAL PROGRAMMING DAN AHP (ANALYTICAL HIERARCHY PROCESS) - 6

Shiddiq Waluyo \& Saiful Haq

- ANALISA TATA LETAK MATERIAL DI GUDANG PT GGS DALAM MENINGKATKAN EFEKTIFITAS KERJA $-12$

Ellysa Kusuma Laksanawati \& Rahman Ridho

- STUDI EKSPERIMENTAL PENGUJIAN KEKASARAN PERMUKAAN DAN KEAKURASIAN DIMENSI PADA PROSES DRY MACHINING BAJA AISI 01 - 17 RIKI CANDRA PUTRA

- ANALISA TINGKAT PENERIMAAN PELANGGAN SELULAR TERHADAP LAYANAN SELULAR BERBASIS 3G PADA PELAJAR SMP DI KABUPATEN TANGERANG $-25$ Triyono

- ANALISIS KELAYAKAN PROYEK PEMBANGKIT LISTRIK TENAGA MINIHIDRO (PLTM) MENGGUNAKAN SOFTWARE RETCSREEN (STUDI KASUS PADA PLTM SIMALUNGUN, SUMATERA UTARA) - 34 Ria Rossaty

- KAPASITAS MOMEN DAN GESER PADA STRUKTUR BALOK DI BANGUNAN TINGGI WILAYAH RAWAN GEMPA - 41 Almufid

- MODEL LAYANAN INFORMASI LOKASI MASJID DI WILAYAH KOTA TANGERANG MENGGUNAKAN PERANGKAT BERGERAK (MOBILE DEVICE) - 49 Angga Aditya Permana

- ANALISA GANGGUAN HUBUNG SINGKAT DENGAN MENGGUNAKAN ETAP 12.6.0 PADA PT X - 60

Badaruddin \& Mochamad Isnan Arsyad

- ANALISIS STRATEgI PEMASARAN OBAT BATUK PROSPAN DENGAN MENGGUNAKAN METODE SWOT PADA PT. SOHO GLOBAL HEALTH - 69 Hermanto \& Ahmad Rizki K.

- MEMBANGUN VOICE OVER INTERNET PROTOCOL (VOIP) MENGGUNAKAN SOFTWARE ASTERISK - 84 Bambang Adi Mulyani 


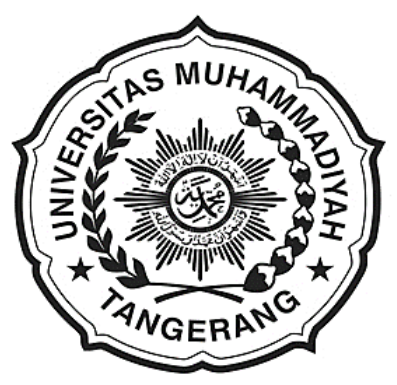

Sambutan Dekan

Fakultas Teknik

Universitas Muhammadiyah Tangerang

Puji Syukur kehadirat Allah Swt. karena berkat karunia dan ijin-Nyalah Tim penyusun Jurnal Teknik Fakultas Teknik Universitas Muhammadiyah Tangerang dapat menyelesaikan tugasnya tepat sesuai dengan waktu ditetapkan.

Saya menyambut baik diterbitkannya Jurnal Teknik Vol. 5 No. 1, Mei 2016, terbitnya jurnal ini, merupakan respon atas terbitnya Peraturan Menteri Pendidikan Nasional No. 17 Tahun 2010 tentang Pencegahan dan Penanggulangan Plagiat di Perguruan Tinggi; Surat Dirjen Dikti Nomor 2050/E/T/2011 tentang kebijakan unggah karya ilmiah dan jurnal; Surat Edaran Dirjen Dikti Nomor 152/E/T/2012 tertanggal 27 Januari 2012 perihal publikasi karya ilmiah yang antara lain menyebutkan untuk lulusan program sarjana terhitung mulai kelulusan setelah 2012 harus menghasilkan makalah yang terbit pada jurnal ilmiah.

Terbitnya Jurnal ini juga diharapkan dapat mendukung komitmen dalam menunjang peningkatan kemampuan para dosen dan mahasiswa dalam menyusun karya ilmiah yang dilandasi oleh kejujuran dan etika akademik. Perhatian sangat tinggi yang telah diberikan rektor Universitas Muhammadiyah Tangerang khususnya mengenai plagiarism dan cara menghindarinya, diharapkan mampu memacu semangat dan motivasi para pengelola jurnal, para dosen dan mahasiswa dalam menyusun karya ilmiah yang semakin berkualitas.

Saya mengucapkan banyak terimakasih kepada para penulis, para pembahas yang memungkinkan jurnal ini dapat diterbitkan, dengan harapan dapat dimanfaatkan seoptimal mungkin dalam peningkatan kualitas karya ilmiah.

Dekan Fakultas Teknik
Universitas Muhammadiyah Tangerang,

Ir. Saiful Haq, M.Si. 


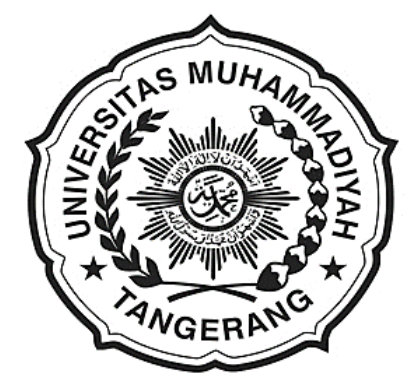

\section{Pengantar Redaksi \\ Jurnal Teknik}

Universitas Muhammadiyah Tangerang

Puji dan Syukur Alhamdulillah kami panjatkan kehadapan Allah Swt. atas karunia dan lindungan-Nya sehingga Jurnal Teknik Vol. 5 No. 1 Bulan September 2016 dapat diterbitkan.

Menghasilkan karya ilmiah merupakan sebuah tuntutan perguruan tinggi di seluruh dunia. Tri Dharma Perguruan Tinggi yaitu darma pendidikan, darma penelitian, dan darma pengabdian kepada masyarakat mendorong lahirnya dinamika intelektual diantaranya menghasilkan karya-karya ilmiah. Penerbitan Jurnal Teknik ini dimaksudkan sebagai media dokumentasi dan informasi ilmiah yang sekiranya dapat membantu para dosen, staf dan mahasiswa dalam menginformasikan atau mempublikasikan hasil penelitian, opini, tulisan dan kajian ilmiah lainnya kepada berbagai komunitas ilmiah.

Buku Jurnal yang sedang Anda pegang ini menerbitkan 11 artikel yang mencakup bidang teknik sebagaimana yang tertulis dalam daftar isi dan terdokumentasi nama dan judul-judul artikel dalam kulit cover Jurnal Teknik Vol. 5 No. 1 bulan Mei 2016 dengan jumlah halaman 1-94 halaman.

Jurnal Teknik ini tentu masih banyak kekurangan dan masih jauh dari harapan, namun demikian tim redaksi berusaha untuk ke depannya menjadi lebih baik dengan dukungan kontribusi dari semua pihak. Harapan Jurnal Teknik akan berkembang menjadi media komunikasi intelektual yang berkualitas, aktual dan faktual sesuai dengan dinamika di lingkungan Universitas Muhammadiyah Tangerang.

Tak lupa pada kesempatan ini kami mengundang pembaca untuk mengirimkan naskah ringkasan penelitiannya ke redaksi kami. Kami sangat berterimakasih kepada semua pihak yang telah membantu penerbitan Jurnal Teknik ini semoga buku yang sedang Anda baca ini dapat bermanfaat.

Pimpinan Redaksi Jurnal Teknik

Universitas Muhammadiyah Tangerang,

Drs. Ir. Sumardi Sadi, MT. 


\title{
ANALISIS STRATEGI PEMASARAN OBAT BATUK PROSPAN DENGAN MENGGUNAKAN METODE SWOT PADA PT. SOHO GLOBAL HEALTH
}

\author{
Hermanto ${ }^{1)}$ dan Ahmad Rizki K. ${ }^{2)}$ \\ Program Studi Teknik Industri \\ FTMIPA Universitas Indraprasta PGRI Jakarta \\ Email: ${ }^{1)}$ her.ruslan@yahoo.co.id; ${ }^{2)}$ hers3sm@gmail.com
}

\begin{abstract}
ABSTRAK
Hasil proses penelitian analisis SWOT yang ada di PT. SOHO Global Health menjelaskan bahwa produk prospan berada pada tahap Growth Oriented Strategi dengan Peluang 1,77 dan kekuatan 2.08. Ini merupakan situasi yang baik dimana perusahaan memiliki kekuatan sehingga dapat memanfaatkan peluang yang ada hingga perusahaan dapat tumbuh berkembang dengan baik dan dapat memasarkan produk Prospan tersebut dipasaran obat ekpektoran di Indonesia. Jadi dapat disimpulkan yang diperoleh dari penelitian ini adalah Berdasarkan hasil uji validitas diperoleh software SPSS 16 dapat diketahui bahwa keseluruhan responden yang diteliti sebanyak 30 dari 14 indikator dinyatakan $100 \%$ valid, maka dapat dikatakan bahwa $\mathrm{r}$ hitung lebih besar dari $r$ tabel. Dari tabel di atas alpha cronbach yang diperoleh diatas 0,80 yaitu sebesar 0,893 maka data tersebut dikatakan reliable (baik). Faktor-faktor yang mempengaruhi kesuksesan PT. SOHO Global Health dilihat dari faktor-faktor internal kekuatan, produk yang mengandung bahan aktif ektrak herbal daun ivy, didukung banyak studi klinis, dan citra perusahaan yang baik didalam memasarkan obat-obat berbahan herbal. Faktor internal kelemahan adalah tidak adanya kemasan tablet/bentuk kapsul, harga yang relatif premium dan keyakinan dokter akan obat-obat alami (herbal) masih lemah. Faktor eksternal peluang adalah pasar (konsumen) mulai aktif mencari obatobatan yang aman yang berbahan dasar herbal dan belum banyaknya beredar obat herbal dengan reputasi farmasi. Faktor eksternal ancaman adalah kegiatan promosi yang aktif dari pesaing (kompetitor) dan obat-obat ekpektoran berbahan kimia sudah banyak tersedia di Indonesia.
\end{abstract}

Kata Kunci: SWOT, Bobot Faktor Internal \& Eksternal, Rating, Analisis Faktor, Matrik SWOT.

\section{PENDAHULUAN}

Memasuki era perdagangan bebas seperti saat ini, perusahaan dihadapkan pada persaingan untuk meraih dominasi pangsa pasar, dimana perusahaan didalam menjalankan aktivitasnya mempunyai tujuan memperoleh keuntungan. Dalam mencapai strategi pemasaran yang tepat dan terbaik untuk di terapkan, PT. SOHO Global Health salah satu perusahan yang bergerak di bidang farmasi memasarkan obat-obatan, salah satunya adalah obat batuk. Batuk merupakan penyakit respiratori dan non-respiratori, obat batuk terdapat banyak jenisnya yaitu antitusif sebagai obat menekan refleks batuk, ekspektoran untuk merangsang dahak dikeluarkan dari saluran pernafasan dan mukolitik untuk mengencerkan dahak. diketahui bahwa obat batuk tidak bisa disama ratakan untuk semua jenis batuk. Oleh sebab itu perlu dicapai pengetahuan yang bener mengenai penggunaan jenis-jenis obat batuk terhadap jenis batuk yang di diderita oleh pasien. Klasifikasi produk obat yang dipasarkan secara umum dibedakan kedalam dua golongan, yaitu golongan obat ethical dan golongan obat bebas (OTC). Golongan obat ethical hanya boleh dibeli berdasarkan resep dari dokter dan berdasarkan peraturan dari Depkes. Jenis obat ini tidak boleh dipromosikan kepada masyarakat luas, sedangkan golongan obat bebas (OTC) boleh dijual dan dipromosikan secara 
bebas. Prospan dari PT. SOHO Global Health termasuk obat batuk dalam golongan ethical dimana pemasaranya melalui resep dokter.

\section{LANDASAN TEORI}

\subsection{Pengertian Strategi Pemasaran}

Pemasaran adalah salah satu kegiatan pokok yang perlu dilakukan oleh perusahaan baik itu perusahaan barang atau jasa dalam upaya untuk mempertahankan kelangsungan hidup usahanya. Dalam bahasa Inggris dikenal dengan nama Marketing, asal kata pemaaran adalah pasar (Market). Hal tersebut disebabkan karena pemasaran merupakan salah satu kegiatan perusahaan, dimana secara langsung berhubungan dengan konsumen. Maka kegiatan pemasaran dapat diartikan sebagai kegiatan manusia yang berlangsung dalam kaitannya dengan pasar. Satu fakta yang tetap bertahan adalah kebutuhan dan keinginan manusia selalu berlimpah. Oleh karena itu seorang pemasar dituntut untuk memahami permasalah pokok di bidangnya dan menyusun strategi agar dapat mencapai tujuan perusahaan. Berikut ini beberapa pengertian mengenai pemasaran: Abdullah. $\mathrm{T}$ \& Tantri. F (2012:2) Pemasaran adalah sebuah system total dari kegiatan bisnis yang dirancang untuk merencanakan, menentukan harga, mempromosikan dan mendistribusikan barang-barang yang dapat memuaskan keinginan dan jasa baik kepada para konsumen saat ini maupun konsumen potensial.

\subsection{Manajemen Pemasaran}

Kunci dari keberhasilan dari pelaksanaan operasional sebuah perusahaan dalam menjalankan bisnisnya tidak lepas dari keberhasilan perusahaan tersebut dalam mengelolah sumber daya yang ada didalamnya. Sumber daya yang dimaksud tentunya tidak hanya sumber daya manusia saja, melainkan didalamnya sumber daya modal, material, teknologi, informasi dan lain-lain. Manajemen tidak hanya dibutuhkan di perusahaan saja, manajemen dibutuhkan dalam semua tipe kegiatan yang di organisasi dan dalam semua tipe organisasi, termasuk didalamnya manajemen pemasaran.

Manajemen pemasaran adalah proses perencanaan dan pelaksanaan konsepsi, penetapan harga, promosi dan distribusi gagasan, barang dan jasa untuk menghasilkan per- tukaran yang memuaskan individu dan memenuhi tujuan organisasi. Tujuan manajemen untuk mempengaruhi tingkat, dan jangkauan waktu, komposisi permintaan, sehingga mampu membantu organisasi mencapai sasaran.

\subsection{Pengertian analisis SWOT}

Analisis SWOT adalah metode perencanaan strategis yang digunakan untuk mengevaluasi kekuatan (strengths), kelemahan (weaknesses), peluang (opportunities), dan ancaman (threats) dalam suatu proyek atau suatu spekulasi bisnis. Keempat faktor itulah yang membentuk akronim SWOT (strengths, weaknesses, opportunities, dan threats). Proses ini melibatkan penentuan tujuan yang spesifik dari spekulasi bisnis atau proyek dan mengidentifikasi faktor internal dan eksternal yang mendukung dan yang tidak dalam mencapai tujuan tersebut. Dengan adanya analisis SWOT maka menejemen dapat mengetahui apa yang menjadi peluang bagi perusahaan dan adanya ancaman yang mungkin timbul. Selain itu menejemen dapat mendeteksi keunggulan-keunggulan perusahaan yang menjadi sumber-sumber kekuatan atau kelemahan-kelemahan yang dimiliki perusahaan. Analisis ini didasarkan pada asumsi bahwa suatu strategi yang efektif akan memaksimalkan kekuatan dan peluang serta meminimalkan kelemahan dan ancaman.

Pemahaman yang baik mengenai strategi dan konsep-konsep lain yang berkaitan sangatlah penting untuk menentukan suksesnya strategi yang akan disusun, konsep-konsep tersebut antara lain meliputi.

1. Distinctive competence: Tindakan yang dilakukan oleh perusahaan agar dapat melakukan kegiatan yang lebih baik dibandingkan dengan pesaingnya.

2. Competitive advantage: Kegiatan spesifik yang dikembangkan oleh perusahaan agar lebih unggul dibandingkan dengan pesaingnya.

Analisis SWOT digunakan untuk membandingkan faktor eksternal dan faktor internal. Faktor eksternal terdiri dari peluang dan ancaman, sedangkan faktor internal terdiri dari kekuatan dan kelemahan.

Dalam analisis SWOT, dilakukan perbandingan antara faktor-faktor strategis internal 
maupun eksternal untuk memperoleh strategi terhadap masing-masing faktor tersebut, kemudian dilakukan skoring. Berdasarkan hasil yang diperoleh kemudian ditentukan fokus rekomendasi strategi.

Kekuatan (Stregth) adalah faktor yang selama ini berhasil dikendalikan sehingga memberikan impact yang positif bagi perusahaan. Kekuatan adalah sumber daya, keterampilan dan keunggulan relative terhadap pesaing dan kebutuhan pasar, serta merupakan kompetensi khusus yang memberikan keunggulan komparatif. Kekuatan dapat terkandung dalam sumber daya keuangan, citra, kepemimpinan pasar, hubungan pembeli pemasok, dan lain-lain.

Kelemahan (Weakness) adalah faktor yang sepenuhnya ada dalam kendali manajemen tetapi tidak berhasil dikendalikan sehingga memberikan impact yang negatif bagi perusahaan. Kelemahan adalah keterbatasan atau kekurangan yang secara serius menghambat kinerja efektif perusahaan.

Peluang (Opportunity) adalah faktor yang ada diluar kendali manajemen, tetapi kemunculannya akan menyajikan suatu peluang sukses bagi perusahaan bila Peluang merupakan situasi penting yang menguntungkan dalam lingkungan perusahaan. Kecenderungan penting merupakan salah satu peluang. Identifikasi pasar yang tadinya terabaikan, perubahan peraturan atau situasi persaingan atau membaiknya hubungan dengan pemasok dapat memberikan peluang bagi perusahaan.

Ancaman (Threat) adalah faktor yang ada diluar kendali manajemen, tetapi bila muncul, maka memiliki potensi untuk mengancam kelangsungan hidup perusahaan. Ancaman merupakan situasi penting yang tidak menguntungkan dalam lingkungan perusahaan, dan merupakan pengganggu utama bagi posisi sekarang atau yang diinginkan perusahaan. Masuknya pesaing baru, lambatnya pertumbuhan pasar, meningkatnya kekuatan tawar-menawar perubahan teknologi dapat menjadi ancaman bagi keberhasilan perusahaan.

\section{METODOLOGI PENELITIAN}

\subsection{Metode Pengumpulan Data}

Pengumpulan data adalah salah satu teknik penelitian yang amat penting yang dapat berupa pernyataan tentang sifat, keadaan, kegiatan tertentu dan sejenisnya. Dalam penelitian ini, penulis menggunakan beberapa teknik dan analisis data yang ada hubungannya dengan masalah yang dibahas. Adapun pengumpulan data yang dilakukan dengan dua cara, yaitu dengan menggunakan data primer dan data sekunder. Data primer diperoleh dari wawancara langsung dengan kepala bagian pemasaran dan Manajer Produk di PT.SOHO Global Health Jakarta sebagai perusahaan yang memasarkan obat batuk Propsan, sedangkan data sekunder diperoleh dari data yang telah dikumpulkan oleh pihak lain yang relevan.

1). Data Primer

Data primer yang di dapat untuk pengumpulan data disini diantaranya adalah sebagai berikut:

a. Data penjualan obat-obat ekspektoran periode Q1 2014;

b. Data kelebihan dan kekurangan produk prospan versus competitor; dan

c. Data man power tim marketing competitor prospan.

2). Data Sekunder

DataSekunder pada PT. SOHO Global Health, yang meliputi:

a. Data penjualan;

b. Data Pangsa Pasar Obat Batuk Berdahak;

c. Data dari perusahaan pesaing; dan

d. Spending budget promosi dari kompetitor.

Agar pencarian dan pengumpulan data dapat diperoleh dengan tingkat validasi yang baik perlu ditetapkan metode dan pengumpulan data. Metode yang digunakan adalah:

1. Observasi: Najib. M (2015:174) Observasi adalah sebuah pengamatan yang melibatkan indera (penglihatan, penciuman, pembau, perasa). Obsevasi dalam penelitian ini sesuai dengan objek penelitian, maka peneliti memilih observasi partisipan. Observasi partisipan yaitu suatu teknik pengamatan dimana peneliti ikut ambil bagian dalam kegiatan yang dilakukan oleh obyek yang diselidiki atau diamati. Observasi ini dilakukan dengan Melakukan pengamatan secara langsung pada PT. SOHO Global 
Health, khususnya pada bagian unit pemasaran dalam melakukan pemasaran obat batuk herbal Prospan.

2. Wawancara: Najib. M (2015:174) Wawancara adalah pengambilan data melalui secara lisan langsung dengan sumber datanya, baik melalui tatap muka atau melalui telepon, teleconference. Melakukan wawancara langsung kepada pihak-pihak yang kompeten di bidangnya, wawancara disini dilakukan dengan kepala bagian pemasaran dan Manajer Produk yang kegiatannya adalah membuat brand plan, kunjungan ked okter diseluruh Indonesia (med ref), dan membut gambaran untuk memasarkan obat baru, yang mana kali ini adalah memasarkan obat batuk berdahak Prospan dari PT. SOHO Global Health. Yang tujuan akhirnya dari sesi wawancara ini adalah untuk mendapatkan data yang relevan sehingga dapat diperoleh informasi yang memadai.

3. Kuesioner: Najib. M (2015:174) Kuesioner adalah daftar pertanyaan tertulis yang ditujukan kepada responden. Jawaban responden atas semua pertanyaan dalam kuesioner kemudian dicatat/direkam.

Dalam penelitian ini peneliti menggunakan kuesioner, sebelumnya perlu diidentifikasi indikator-indikator yang ingin ditanyakan dalam kuesioner SWOT. Cara mengidentifikasi indikator SWOT disini adalah dengan menggunakan kajian litelatur, wawancara. Lalu kuesioner yang telah dibuat yang berisikan sejumlah pertanyaan yang berkaitan dengan tujuan penelitian diambil sampelnya dan diberikan kepada responden dalam hal ini adalah internal perusahaan (bagian pemasaran).

\subsection{Instrument Penelitian}

Arikunto. S (2013:203) Instrumen penelitian adalah alat atau fasilitas yang digunakan oleh peneliti dalam pengumpulan data agar pekerjaannya lebih mudah dan hasilnya lebih baik, dalam arti lebih cermat, lengkap dan sistematis sehingga lebih mudah diolah.

Ditinjau dari karakteristik masalah yang diteliti, penelitin ini diklasifikasikansebagai model penelitiaan deskriftif. Penelitian deskriptif merupakan penelitian terhadap masa- lah-masalah berupa fakta-fakta saat ini dari suatu populasi yang bertujuan untuk menguji atau menjawab pertanyaan yang berkaitan dengan status saat ini dari subjek yang di teliti.

\subsection{Teknik Analisis Data}

Teknik analisis data ini dilakukan dengan strategi pemasaran menggunakan metode SWOT dengan menganalisis kompetitor yang ada serta menganalisi pasar pada obat batuk berdahak di Indonesia. Agar obat yang akan di pasarkan ini mendapatkan pangsa pasar dan market share yang di inginkan perusahaan. Oleh karena ini sebelum memasarkan obat batuk brrdahak dari PT.SOHO Global Health ini maka perlu di lakukan analisis market dan analisis kompetitornya terlebih dahulu. Memasarkan obat Prospan dengan melihat data penjualan obat batuk sejenis di pasaran dan dengan menganalisis beberapa faktor: 1) Sekmentasi pasar; 2). Riset pasar; 3). Penentuan posisi didalam pasar (positioning); dan 4). Penentuan sekmen dari porsi pasar (targeting)

Serta teknis analisis data disini menggunakan data internal dan eksternal yang terdapat pada metode SWOT yang digunakan perusahaaan.

\section{HASIL PENELITIAN DAN PEMBAHASAN}

\subsection{Sejarah Singkat PT. SOHO Global Health}

PT. Ethica adalah perusahaan pertama yang didirikan oleh Tan Tjhoen Lim pada tahun 1946. Pada awalnya, perusahaan ini bernama NV Ethica Handel MY, kemudian nama tersebut diubah menjadi PT. Ethica Industri Farmasi. PT. Ethica Industri Farmasi adalah perusahaan pertama memproduksi obat suntik oleh karenaitulah PT. Ethica Industri Farmasi menjadi perusahaan pelopor untuk obat di pasar resep. Sebuah anak perusahaan yaitu, PT. SOHO Industri Pharmasi didirikan pada tahun 1951. Nama itu diambil dari sebuah kata dalam bahasa latin yaitu SOHO yang memiliki kepanjangan Societas HONORABILIS dan mempunyai arti masyarakat terhormat. PT. SOHO memproduksi obat oral. PT. SOHO juga menjadi pelopor dan trendsetter dalam untuk produk berbahan dasar alami dalam pasar resep. Pada tahun 1996, PT. SOHO memasuki pasar over the 
counter (OTC)

\subsection{Pengumpulan Data}

Dalam proses pengolahan data dan analisis penelitian pembahasan dibutuhkan data. Pengumpulan data yang dilakukan penulis di PT. SOHO Global Health meliputi data-data penjualan serta wawancara langsung kepada Product Manager Speciality Professional Product yang ada di PT. SOHO Global Health. Dimana didalam hasil wawancaraa yang dilakukan diperoleh data pada perusahaan kompetitora sebagai bahan perbandingan gambaran untuk memasarkan obat batuk Prospan di Indonesia. Dimana kompetiror utama pemasaran produk prospan dalam memasarkan obat baru dari PT. SOHO Global Health ini adalah ketiga kompetitor utama yaitu: Mucopect, Flumuncil dan Vectrine dimana ketiga produk tersebut memiliki pertumbuhan dan pangsa pasar yang baik di obat expektoran di Indonesia.

\subsection{Pengolahan Data}

Pengolahan data dilakukan dengan menyebarkan angket/kuesioner yang bertujuan untuk melihat penggaruh strategi pemasaran pada produk obat-obat ekspektoran yang ada di PT. SOHO Global Health serta untuk mengetahui strategi apa yang akan diambil untuk memasarakan produk obat batuk Prospan ini. Dibawah ini merupakan informasi angket/kuesioner yang ada pada penelitian yang dilakukan, diantaranya antara lain:

Keterangan bobot skor:

$\begin{array}{ll}\text { Sangat Tidak Setuju (STS) } & =1 \\ \text { Tidak Setuju (TS) } & =2 \\ \text { Kurang Setuju (KS) } & =3 \\ \text { Setuju (S) } & =4 \\ \text { Sangat Setuju (SS) } & =5\end{array}$

Keterangan kode butir pernyataan kuesioner:

$\mathrm{S}=$ Strenght (Kekuatan)

$\mathrm{W}=$ Weakness (Kelemahan)

$\mathrm{O}=$ Opportunity (Peluang)

$\mathrm{T}=$ Treat (Ancaman)

\section{1). Data skor hasil penyebaran kuesioner}

Tabel 4.1 Data uji skor hasil dari penyebaran kuesioner

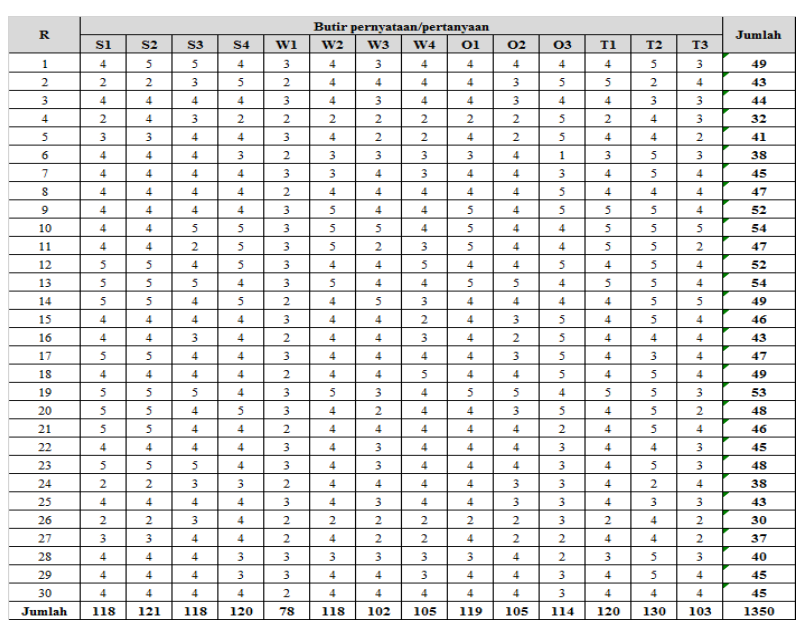

Sumber: Responden PT. SOHO Global Health

\section{2). Identifikasi SWOT}

Strategi perusahaan dalam pengembangan produk (Prospan) dengan menggunakan Analisis SWOT:

1. Faktor Internal

a. Strengths (Kekuatan)

1. Mengandung bahan aktif ekstrak herbal daun ivy

2. Didukung banyak studi klinis lebih dari 160 penelitian berskala internasional.

3. Citra perusahaan baik didalam memasarkan obat-obat berbahan natural.

4. Manfaat dan khasiat yang sangat baik dan profil keamanan yang tinggi.

b. Weaknesses (Kelemahan)

1. Perusahaaan belum dekat dengan target dokter (dokter anak dan dokter paru).

2. Tidak ada kemasan tablet/bentuk kapsul.

3. Harga yang relative premium.

4. Keyakinan dokter akan obatobatan alami (herbal) masih lemah.

2. Faktor Eksternal

a. Opportunities (Peluang)

1. Pasar (konsumen) mulai aktif mencari obat-obat yang aman yang berbahan dasar herbal.

2. Belum banyaknya beredar obat herbal dengan reputasi farmasi. 
3. Kebutuhan masyarakat yang semakin beragam.

b. Threats (Ancaman)

1. Kegiatan promosi yang aktif dari pesaing (kompetitor)

2. Peraturan pemerintah yang membatasi gerak promosi dari perusahaaan lokal.

3. Obat-obat ekpektoran berbahan kimia sudah banyak tersedia di Indonesia.

\section{3). Analisis Pembahasan}

Setelah melakukan pengolahan data uji skor angket/kuesioner menggunakan software SPSS versi 16 dengan tingkat signifikan 5\%, maka dilakukan analisis disetiap pengujian nya. Di bawah ini merupakan hasil analisis strategi pemasaran dengan menggunakan metode SWOT yang ada PT. SOHO Global Health diantara lain:

a). Analisis pengujian validitas

Uji Validitas adalah tingkat keandalan dan kesahihan alat ukur yang digunakan. Instrumen dikatakan valid jika menunjukan alat ukur yang valid atau dapat digunakan untuk mengukur seseatu yang seharusnya diukur (Najib. M, 2015: 234 mengutip dari Sugiyono, 2004:137). Di bawah ini merupakan tabel output dari pengujian validitas:

Tabel 4.3 Case Processing Summary

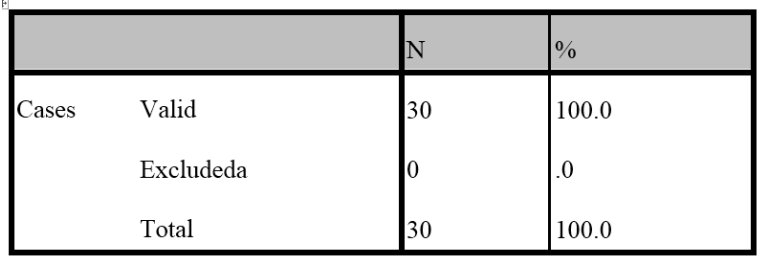

Sumber: Pengolahan data SPSS 16

Dari table 4.3 diatas menjelaskan bahwa 30 kasus telah diproses atau $100 \%$ sudah valid. Hal tersebut menjelaskan bahwa 30 kasus telah diproses valid Dari hasil pengolahan data menggunakan software SPSS 16 dapat diketahui bahwa keseluruhan responden yang diteliti sebanyak 30 dari 14 indikator dinyatakan $100 \%$ valid, maka dapat dikatakan bahwa $\mathrm{r}$ hitung lebih besar dari $\mathrm{r}$ tabel. Dibawah ini merupakan hasil output dari item total statistic yang telah dilakukan pengujian melaluji uji validitas pada SPSS 16 yaitu, sebagai berikut:

\begin{tabular}{|l|r|r|r|r|}
\hline & $\begin{array}{r}\text { Scale Mean if } \\
\text { Item Deleted }\end{array}$ & $\begin{array}{c}\text { Scale } \\
\text { Variance if } \\
\text { Item Deleted }\end{array}$ & $\begin{array}{c}\text { Corrected } \\
\text { Item-Total } \\
\text { Correlation }\end{array}$ & $\begin{array}{c}\text { Cronbach's } \\
\text { Alpha if Item } \\
\text { Deleted }\end{array}$ \\
\hline S1 & 48.4333 & 40.530 & .739 & .847 \\
S2 & 48.3333 & 42.299 & .624 & .855 \\
S3 & 48.4333 & 45.082 & .511 & .861 \\
S4 & 48.3667 & 45.482 & .464 & .863 \\
W1 & 49.7667 & 47.289 & .405 & .866 \\
W2 & 48.4333 & 42.737 & .726 & .851 \\
W3 & 48.9667 & 43.344 & .524 & .860 \\
W4 & 48.8667 & 43.016 & .580 & .857 \\
O1 & 48.4000 & 42.662 & .760 & .850 \\
O2 & 48.8667 & 42.051 & .673 & .852 \\
O3 & 48.5667 & 46.323 & .168 & .887 \\
T1 & 48.3667 & 42.930 & .701 & .852 \\
T2 & 48.0333 & 45.344 & .331 & .872 \\
T3 & 48.9333 & 44.340 & .458 & .864 \\
\hline
\end{tabular}

Sumber: Pengolahan data SPSS 16

Pada tabel 4.4 dilakukan perhitungan untuk mencari nilai $r$ tabel dengan ketentuan (df = populasi/jumlah kasus -2 ), maka dapat diketahui bahwa df $=30-2=28$ dengan tingkat signifikan $5 \%(0,05)$ didapat bahwa nilai $r$ tabel sebesar 0,374. Pada tabel tersebut dibandingkan dengan angka $\mathrm{r}$ tabel sebesar 0,374 dan dapat dilihat hasil dari corrected item total correlation pada butir pernyataan O3 dengan nilai 0,168 dan $\mathrm{T} 2$ dengan nilai 0,331 nilainya lebih kecil dari $\mathrm{r}$ tabel yang telah ditentukan dengan taraf significant sebesar $5 \%$ yaitu sebesar 0,374. Pada pengujian validitas bila $r$ hasil lebih kecil dari $r$ tabel maka data/butir pernyataan harus dilakukan iterasi untuk mendapatkan hasil yang valid.

Dibawah ini tabel item statistic yang telah dilakukan iterasi sebanyak 3 (tiga) kali sehingga mendapatkan hasil yang valid:

Tabel 4.5 Item-Total Statistics

\begin{tabular}{|l|c|c|r|r|}
\hline & $\begin{array}{c}\text { Scale } \\
\text { Mean if } \\
\text { Item } \\
\text { Deleted }\end{array}$ & $\begin{array}{c}\text { Scale } \\
\text { Variance } \\
\text { if Item } \\
\text { Deleted }\end{array}$ & $\begin{array}{c}\text { Corrected } \\
\text { Item-Total } \\
\text { Correlation }\end{array}$ & $\begin{array}{c}\text { Cronbach's } \\
\text { Alpha if } \\
\text { Item } \\
\text { Deleted }\end{array}$ \\
\hline S1 & 33.7000 & 26.769 & .709 & .877 \\
S2 & 33.6000 & 28.386 & .570 & .887 \\
S3 & 33.7000 & 30.079 & .531 & .889 \\
W2 & 33.7000 & 28.493 & .702 & .878 \\
W3 & 34.2333 & 28.185 & .590 & .886 \\
W4 & 34.1333 & 28.120 & .627 & .883 \\
O1 & 33.6667 & 28.437 & .735 & .877 \\
O2 & 34.1333 & 27.292 & .728 & .875 \\
T1 & 33.6333 & 28.654 & .676 & .880 \\
T3 & 34.2000 & 29.062 & .517 & .890 \\
\hline
\end{tabular}

Sumber: Pengelolahan data SPSS 16 
Dari nilai $\mathrm{r}$ hasil/corrected item-total correlation yang ada maka semua data dapat dinyatakan valid karena tidak ada yang dibawah nilai $r$ table 0,374 .

b). Analisis pengujian reliabilitas

Menurut Najib. M, 2015:235 mengutip dari Harrison, 2006 uji reliabilitas adalah ukuran yang menunjukan bahwa alat ukur yang digunakan didalam penelitian mempunyai keandalan sebagai alat ukur, diantaranya diukur melalui konsistensi hasil pengukuran dari waktu ke waktu jika fenomena yang diukur tidak berubah. Standar yang digunakan dalam menentukan reliable dan tidaknya suatu instrument penelitian umumnya adalah perbandingan nilai $r$ hitung dengan $r$ tabel. $r$ tabel yang diperoleh dari hasil iterasi selama 3 kali adalah seperti tabel dibawah ini:

Tabel 4.6 Reliability Statistics

\begin{tabular}{|c|c|}
\hline Cronbach's Alpha & N of Items \\
\hline .893 & 10 \\
\hline
\end{tabular}

Sumber: Pengolahan data SPSS 16

Jika nilai koefisien reliabilitas Cronbach'Alpha yang baik adalah diatas 0,7 (cukup baik) dan diatas 0,8 (baik). (Najib. M, 2015:236 mengutip dari Sugiyono, 2007:137). Dari tabel di atas alpha cronbach yang diperoleh diatas 0,80 yaitu sebesar 0,893 maka data tersebut dikatakan reliable (baik).

\begin{tabular}{|l|c|c|r|r|}
\multicolumn{5}{c|}{ Tabel 4.7 Item- Total Statistic } \\
\hline & $\begin{array}{c}\text { Scale } \\
\text { Mean if } \\
\text { Item } \\
\text { Deleted }\end{array}$ & $\begin{array}{c}\text { Scale } \\
\text { Variance if } \\
\text { Item } \\
\text { Deleted }\end{array}$ & $\begin{array}{c}\text { Corrected } \\
\text { Item-Total } \\
\text { Correlation }\end{array}$ & $\begin{array}{c}\text { Cronbach's } \\
\text { Alpha if } \\
\text { Item } \\
\text { Deleted }\end{array}$ \\
\hline S1 & 33.7000 & 26.769 & .709 & .877 \\
S2 & 33.6000 & 28.386 & .570 & .887 \\
S3 & 33.7000 & 30.079 & .531 & .889 \\
W2 & 33.7000 & 28.493 & .702 & .878 \\
W3 & 34.2333 & 28.185 & .590 & .886 \\
W4 & 34.1333 & 28.120 & .627 & .883 \\
O1 & 33.6667 & 28.437 & .735 & .877 \\
O2 & 34.1333 & 27.292 & .728 & .875 \\
T1 & 33.6333 & 28.654 & .676 & .880 \\
T3 & 34.2000 & 29.062 & .517 & .890 \\
\hline
\end{tabular}

Sumber: Pengolahan data SPSS 16

Dari tabel di atas alpha cronbach yang diperoleh diatas 0,80 yaitu sebesar 0,893 maka data tersebut dikatakan reliabel.

\subsection{Perhitungan Bobot Faktor Internal dan Eksternal}

Perhitungan bobot ini bertujuan untuk memberikan penilaian atau bobot mengenai seberapa besar pengaruh masing-masing pernyataan yang telah dibuat pada internal dan eksternal perusahaan terhadap kesuksesan perusahaan. Pemberian bobot mulai dari 1,0 (sangat penting) sampai 0,0 (tidak penting). Faktor-faktor tersebut kemungkinan dapat memberikan dampak terhadap faktor strategis perusahaan.

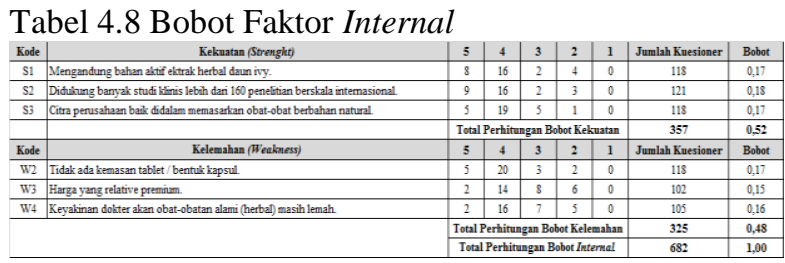

Sumber: Kuesioner PT. SOHO Global Health

Sebelum melakukan perhitungan bobot maka dilakukanlah perhitungan pengolahan data kuesioner dengan cara, contoh sebagai berikut:

$$
\mathrm{S} 1=(5 \times 8)+(4 \times 16)+(3 \times 2)+(2 \times 4)
$$
$+(1 \times 0)=118$. Berdasarkan dari pada table 4.8 diatas di dapat hasil total pengolahan data kuesioner kekuatan (Strengt) adalah 357, dan hasil pengolahan data kuesioner untuk indikator kelemahan (Weakness) di dapatkan hasil sebesar 325 dengan demikian total perhitungan nilai pengolahan data kuesioner faktor internal (kekuatan dan kelemahan) sebanyak 682. Kemudian dari hasil perhitungan pengolahan data tersebut dilakukan perhitungan bobot internal dengan rumus:

Rumus Bobot $=\frac{\text { Nilai pengolahan data kuesioner }}{\text { Total nilai pengolahan data kuesioner }}$

Dari perhitungan bobot faktor internal perusahaan pada tabel 4.8 dapat diketahui bahwa total bobot dari kekuatan didapat nilai sebesar 0,52 sedangkan total bobot kelemahan didapat nilai sebesar 0,48 . Sehingga dengan demikian total perhitungan bobot internal didapat nilai sebesar 1,00 .

Sehingga dengan total bobot tersebut sangat penting atau faktor-faktor tersebut kemungkinan dapat memberikan dampak terhadap faktor strategis perusahaan. 
Tabel 4.9 Bobot Faktor Eksternal

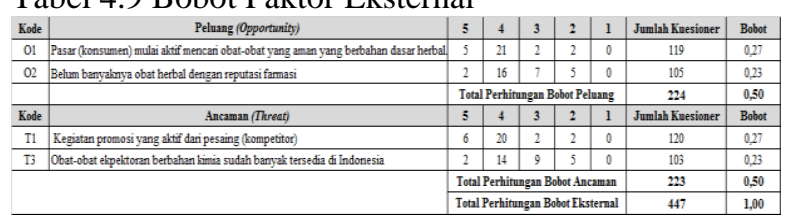

Sumber: Kuesioner PT. SOHO Global Health

Selanjutnya melakukan analisis pehitungan bobot perhitungan faktor eksternal yang meliputi indikator peluang (Opportunity) dan indikator ancaman (Threat).

Rumuh perhitungan yang digunakan sama dengan perhitungan bobot faktor internal (kekuatan dan kelemahan) pada tabel $4.8 \mathrm{~d}$ iatas yang mana diperoleh hasil total pengolahan data kuesioner indikator peluang (Oportunity) adalah 224 dan hasil pengolahan data kuesioner indikator ancaman (Threat) didapatkan hasil sebesar 223 dengan demikian total perhitungan nilai pengolahan data kuesioner faktor eksternal (peluang dan ancaman) diperoleh data sebanyak 447 . Sehingga dari hasil perhitungan pengolahan data tersebut dilakukan perhitungan bobot eksternal dengan rumus:

Rumus Bobot $=\frac{\text { Nilai pengolahan data kuesioner }}{\text { Total nilai pengolahan data kuesioner }}$

Dari perhitungan bobot faktor eksternal perusahaan pada tabel 4.9 dapat diketahui bahwa total bobot dari indikator peluang (opportunity) didapatkan hasil nilai sebesar 0,50 sedangkan total bobot dari indikator ancaman (Threat) didapatkan hasil nilai sebesar 0,50. Sehingga dengan demikian total perhitungan bobot eksternal didapatkan nilai sebesar 1,00. Sehingga dengan total bobot tersebut sangat penting atau faktor-faktor tersebut kemungkinan dapat memberikan dampak terhadap faktor strategis perusahaan.

\subsection{Pemberian Nilai Rating}

Pemberian nilai rating untuk variabel yang meliputi indikator faktor internal kekuatan dan kelemahan dan faktor eksternal untuk variabel peluang dan ancaman.

\section{1). Rating Faktor Internal}

Indikator kekuatan diberi nilai 1 sampai dengan 4.

1. Diberi nilai 1 jika kemungkinan indikator tersebut dinilai kinerjanya semakin menurun dibandingkan dengan pesaing utama.
2. Nilai 2 jika indikator tersebut kinerjanya sama dibandingkan dengan pesaing utama.

3. Sedangkan diberi nilai 3 atau 4 jika indikator tersebut lebih baik dibandingkan pesaing utama.

Dengan demikian semakin tinggi nilainya artinya kinerja indikator tersebut akan semakin baik dibandingkan pesaing utamanya. Sedangkan untuk indikator kelemahan:

1. Diberi nilai 1 jika indikator tersebut kinerjanya semakin banyak kelemahannya dari pesaing utamanya.

2. Sebaliknya diberi nilai 4 kelemahan indikator tersebut semakin menurun dibandingkan pesaing utamanya rating.

\section{2). Faktor Eksternal}

Indikator peluang pada faktor eksternal ini pemberian nilai ratingnya sama seperti penjelasan yang diberikan pada faktor internal diatas, dimana indikator peluang (opportunity) dan ancaman (treath) diberi nilai 1 sampai dengan 4 .

Tabel 4.10 Rating Faktor Internal dan Eksternal

\begin{tabular}{|c|c|c|c|c|c|c|c|c|c|c|c|}
\hline \multicolumn{8}{|l|}{ Intemal } & \multicolumn{4}{|c|}{ Eksternal } \\
\hline R & S1 & S2 & S3 & W2 & W3 & W4 & R & Ol & $\mathrm{O} 2$ & $\mathrm{~T} 1$ & T3 \\
\hline 1 & 4 & 5 & 5 & 4 & 3 & 4 & 1 & 4 & 4 & 4 & 3 \\
\hline 2 & 2 & 2 & 3 & 4 & 4 & 4 & 2 & 4 & 3 & 5 & 4 \\
\hline 3 & 4 & 4 & 4 & 4 & 3 & 4 & 3 & 4 & 3 & 4 & 3 \\
\hline 4 & 2 & 4 & 3 & 2 & 2 & 2 & 4 & 2 & 2 & 2 & 3 \\
\hline 5 & 3 & 3 & 4 & 4 & 2 & 2 & 5 & 4 & 2 & 4 & 2 \\
\hline 6 & 4 & 4 & 4 & 3 & 3 & 3 & 6 & 3 & 4 & 3 & 3 \\
\hline 7 & 4 & 4 & 4 & 3 & 4 & 3 & 7 & 4 & 4 & 4 & 4 \\
\hline 8 & 4 & 4 & 4 & 4 & 4 & 4 & 8 & 4 & 4 & 4 & 4 \\
\hline 9 & 4 & 4 & 4 & 5 & 4 & 4 & 9 & 5 & 4 & 5 & 4 \\
\hline 10 & 4 & 4 & 5 & 5 & 5 & 4 & 10 & 5 & 4 & 5 & 5 \\
\hline 11 & 4 & 4 & 2 & 5 & 2 & 3 & 11 & 5 & 4 & 5 & 2 \\
\hline 12 & 5 & 5 & 4 & 4 & 4 & 5 & 12 & 4 & 4 & 4 & 4 \\
\hline 13 & 5 & 5 & 5 & 5 & 4 & 4 & 13 & 5 & 5 & 5 & 4 \\
\hline 14 & 5 & 5 & 4 & 4 & 5 & 3 & 14 & 4 & 4 & 4 & 5 \\
\hline 15 & 4 & 4 & 4 & 4 & 4 & 2 & 15 & 4 & 3 & 4 & 4 \\
\hline 16 & 4 & 4 & 3 & 4 & 4 & 3 & 16 & 4 & 2 & 4 & 4 \\
\hline 17 & 5 & 5 & 4 & 4 & 4 & 4 & 17 & 4 & 3 & 4 & 4 \\
\hline 18 & 4 & 4 & 4 & 4 & 4 & 5 & 18 & 4 & 4 & 4 & 4 \\
\hline 19 & 5 & 5 & 5 & 5 & 3 & 4 & 19 & 5 & 5 & 5 & 3 \\
\hline 20 & 5 & 5 & 4 & 4 & 2 & 4 & 20 & 4 & 3 & 4 & 2 \\
\hline 21 & 5 & 5 & 4 & 4 & 4 & 4 & 21 & 4 & 4 & 4 & 4 \\
\hline 22 & 4 & 4 & 4 & 4 & 3 & 4 & 22 & 4 & 4 & 4 & 3 \\
\hline 23 & 5 & 5 & 5 & 4 & 3 & 4 & 23 & 4 & 4 & 4 & 3 \\
\hline 24 & 2 & 2 & 3 & 4 & 4 & 4 & 24 & 4 & 3 & 4 & 4 \\
\hline 25 & 4 & 4 & 4 & 4 & 3 & 4 & 25 & 4 & 3 & 4 & 3 \\
\hline 26 & 2 & 2 & 3 & 2 & 2 & 2 & 26 & 2 & 2 & 2 & 2 \\
\hline 27 & 3 & 3 & 4 & 4 & 2 & 2 & 27 & 4 & 2 & 4 & 2 \\
\hline 28 & 4 & 4 & 4 & 3 & 3 & 3 & 28 & 3 & 4 & 3 & 3 \\
\hline 29 & 4 & 4 & 4 & 4 & 4 & 3 & 29 & 4 & 4 & 4 & 4 \\
\hline 30 & 4 & 4 & 4 & 4 & 4 & 4 & & 4 & 4 & 4 & 4 \\
\hline Jumlah & 118 & 121 & 118 & 118 & 102 & 105 & Jumlah & 119 & 105 & 120 & 103 \\
\hline \multirow{2}{*}{ Rating } & 3,80 & 3,91 & 3,87 & 3,85 & 3,27 & 3,38 & \multirow{2}{*}{ Rating } & 3,89 & 3,38 & 3,92 & 3,32 \\
\hline & 4 & 4 & & 4 & 3 & 4 & & 4 & & 4 & 3 \\
\hline
\end{tabular}

Sumber: kuesioner PT.SOHO Global Health

Pemberian Rating untuk faktor internal dan eksternal ini menggunakan cara perhitu- 
ngan sebagai berikut: Total Perkalian responden $(\mathrm{S} 1)$ :

Total Perkalian responden S1:

$4 * 2 * 4 * 2 * 3 * 4 * 4 * 4 * 4 * 4 * 4 * 5 * 5 * 5 * 4 * 4 * 5 * 4 * 5$ $* 5 * 5 * 4 * 5 * 2 * 4 * 2 * 3 * 4 * 4 * 4$

Jumlah responden: 30

Rating untuk faktor tersebut:

$$
\begin{gathered}
30 \sqrt{\begin{array}{r}
4 * 2 * 4 * 2 * 3 * 4 * 4 * 4 * 4 * 4 * 4 * \\
5 * 5 * 5 * 4 * 4 * 5 * 4 * 5 * 5 * 5 * 4 * \\
5 * 2 * 4 * 2 * 3 * 4 * 4
\end{array}} \\
\quad=3,80=4
\end{gathered}
$$

\subsection{Analisis Faktor Internal menggunakan tabel IFAS}

Setelah faktor-faktor strategis internal PT. SOHO Global Health diidentifikasi, disusunlah tabel IFAS (Internal Factors Analysis Summary) disusun untuk merumuskan faktor-faktor strategis internal dalam krangka Strenght and Weakness perusahaan. Tahapannya adalah sebagai berikut:

a. Pada kolom pertama, masukkan faktorfaktor yang menjadi kekuatan dan kelemahan PT. SOHO Global Health yang didapatkan dari hasil pernyataan dari wawancara dengan pihak internal perusahaan pada unit sales and marketing.

b. Pada kolom kedua yaitu bobot, memasukan bobot masing-masing faktor internal yang telah dihitung pada tahap perhitungan faktor bobot dengan skala mulai dari 1,0 (paling penting) sampai 0,0 (tidak penting), berdasarkan pengaruh faktor-faktor tersebut terhadap posisi strategis perusahaan. (semua bobot tersebut jumlahnya tidak boleh melebihi skor total 1,00).

c. Pada kolom ketiga yaitu rating, rating masing-masing faktor internal yang telah dihitung pada tahap perhitungan rating dimasukan pada kolam ketiga. Nilai yang dimasukkan ke dalam tabel IFAS harus genap, maka nilai dari perhitungan rating nilainya dibulatkan menjadi bilangan bulat, seperti 3,80 dibulatkan nilainya menjadi 4.

d. Pada terakhir pada kolam ke empat, yaitu kolam perkalian antara bobot dan rating dimana masing-masing faktor bobot dan rating dilakukan perkalian untuk mendapatkan nilai skornya.

e. Jumlahkan skor pembobotan, untuk memperoleh total skor pembobotan bagi perusahaan.

Tabel 4.11 Internal Factors Analysis Summary (IFAS)

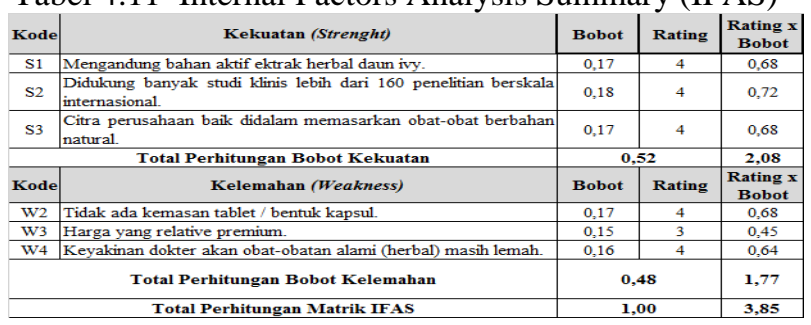

Sumber: kuesioner PT.SOHO Global Health

Dari hasil analisis pada tabel 4.11 diatas, dapat diketahui bahwa faktor kekuatan (strength) memperoleh total nilai skor 2,08 dengan total nilai bobot yang diperoleh sebesar 0,52. Sedangkan pada analisis faktor kelemahan (weakness) memperoleh total nilai skor 1,77 dengan nilai bobot 0,48 dengan keseluruhan jumlah perhitungan matrik IFAS diperoleh skor 3,84 untuk perkalian rating dan bobot, serta 1,00 untuk total keseluruhan bobot faktor internal.

\subsection{Analisis Faktor Eksternal mengguna- kan tabel EFAS}

Tabel 4.12 Eksternal Factors Analysis Summary (EFAS)

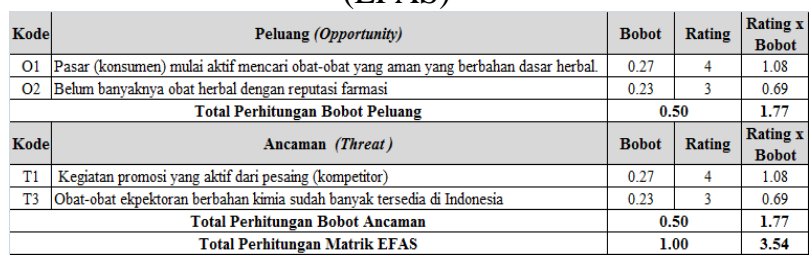

Sumber: kuesioner PT. SOHO Global Health

Dari hasil analisis faktor ekstrenal pada tabel 4.12 diatas, dapat diketahui bahwa faktor peluang (opportunity) memperoleh total nilai skor 1,77 dengan total nilai bobot yang diperoleh sebesar 0,50. Sedangkan pada analisis faktor ancaman (threat) memperoleh total nilai skor 1,77 dengan nilai bobot 0,50 dengan keseluruhan jumlah perhitungan matrik EFAS diperoleh skor 3,54 untuk penjumlahan total bobot peluang dan ancaman, serta 1,00 untuk total keseluruhan bobot faktor eksternal. 


\section{ANALISIS DATA}

\subsection{Diagram Analisis SWOT}

Dari hasil identifikasi faktor-faktor internal dan eksternal pada analisis SWOT sebelumnya, maka dapat digambarkan dalam diagram analisis SWOT. Gambar ini didapat dari informasi pengolahan data pada matrik IFAS dan EFAS.

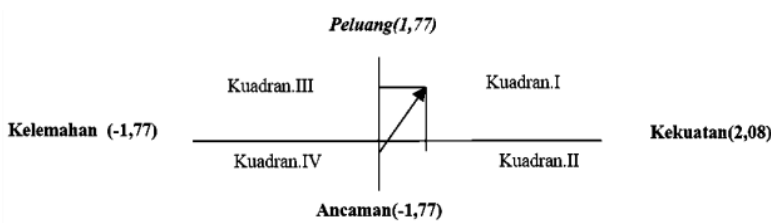

Gambar 4.2 Diagram Analisis SWOT PT. SOHO Global Health

Sumber: analisis PT. SOHO Global Health

Dari diagram analisis SWOT pada gambar 4.2 dapat diketahui bahwa kondisi perusahaan berada pada kuadran I, yang menyatakan bahwa PT. SOHO Global Health berada pada tahap Growth Oriented Strategi. Ini merupakan situasi yang baik dimana perusahaan memiliki kekuatan sehingga dapat memanfaatkan peluang yang ada hingga perusahaan dapat tumbuh berkembang dengan baik dan dapat memasarkan produk Prospan tersebut dipasaran obat ekpektoran di Indonesia.

\subsection{Matrik SWOT}

Pengolahan data pada analisis yang dilakukan di matrik SWOT ini didapat dari analisis IFAS dan EFAS untuk menggambarkan secara jelas bagaimana peluang dan ancaman dari faktor eksternal yang dihadapi perusahaan dapat disesuaikan dengan kekuatan dan kelemahan dari faktor internal PT. SOHO Global Health. Matrik SWOT ini menghasilkan empat set kemungkinan alternatif strategis yaitu: SO, WO, ST, WT.

Dari nilai total masing-masing faktor internal dan eksternal tersebut selain dapat digambarkan dalam sebuah diagram analisis SWOT juga digambarkan dalam rumusan kombinasi matrik SWOT, seperti dapat dilihat pada tabel 4.13 dibawah ini.

Tabel 4.13 Rumusan Kombinasi Matrik SWOT PT. SOHO Global Health

\begin{tabular}{|c|c|c|}
\hline EFAS IFAS & STRENGHS (S) & WEAKNESS (W) \\
\hline OPPORTUNITIE (O) & $\begin{array}{c}\text { Strategi SO: } \\
2.08+1.77=3.85\end{array}$ & $\begin{array}{c}\text { Strategi WO: } \\
1.77+1.77=3.54\end{array}$ \\
\hline TREATHS (T) & $\begin{array}{c}\text { Strategi ST: } \\
2.08+1.77=3.85\end{array}$ & $\begin{array}{c}\text { Strategi WT: } \\
1.77+1.77=3.54\end{array}$ \\
\hline
\end{tabular}

Sumber : analisis PT. SOHO Global Health
Dari analisis matrik IFAS dan EFAS sebelumnya, telah disusun pula matrik SWOT untuk menganalisis rumusan alternatif strategi SO, ST, WO, WT yang dimana hasil analisisnya seperti pada tabel 4.13. Rumusan alternatif strategi adalah pilihan-pilihan alternatif strategi yang digunakan perusahaan untuk menjalani bisnisnya tersebut. Rumusan alternatif strategi digunakan setelah mengetahui hasil dari perhitungan pada tabel 4.14. Berikut ini adalah rumusan alternatif strateginya:

Tabel 4.14 Kombinasi Matrik SWOT PT. SOHO Global Health

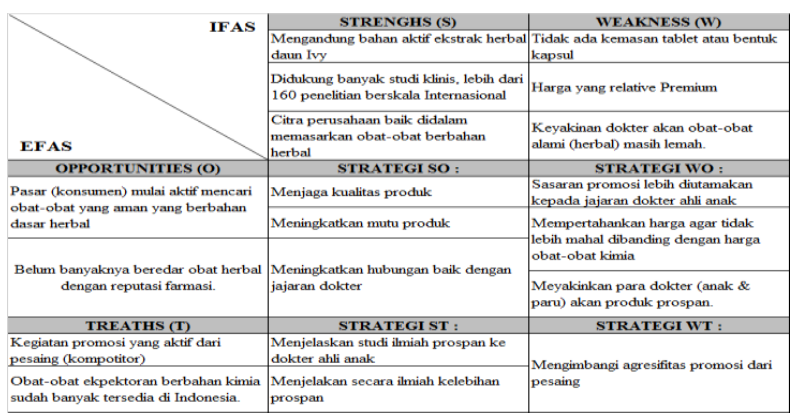

Sumber: analisis PT. SOHO Global Health

\subsection{Analisis Matrik SWOT Untuk Strategi SO}

Menggunakan faktor kekuatan untuk memanfaatkan peluang dalam memperbesar penjualan produk Prospan.

1) Menjaga kualitas produk.

Menjaga kualitas produk adalah salah satu kunci keberhasilan perusahaan, oleh karen itu pada faktor menjaga kualitas produk disini perusahan dalam hal ini PT. SOHO Global Health harus membuat standar operasional produk yang akan di pasarkan. Dimana didalam menjaga kualitas produk disini harus mencangkup beberapa faktor diantaranya adalah: faktor kemasan dan bahan baku yang jadi faktor utama dalam menjaga kualitas produk.

2) Meningkatkan mutu produk

Produk yang baik adalah produk yang bermutu. Didalam persaingan dunia bisnis khusunya dunia farmasi yang semakin ketat, perusahaan diharuskan untuk terus melakukan peningkatan pada sisi mutu produk. Tujuan dari meningkatkan mutu produk disini adalah strategi untuk menarik pelanggan milik pesaing, dengan memberikan berbagai kelebihan yang dimiliki produk Prospan seperti: mengandung zat aktif yang berasal dari ektrak tumbuhan dimana warnanya dapat bervariasi, 
terbukti secara klinis aman, efektif, bebas gula, bebas zat pewarna, serta sudah diresepkan di lebih dari 91 negara di dunia dan merek yang direkomendasikan dokter anak di Jerman.

\section{3) Meningkatkan hubungan baik dengan jajaran Dokter.}

Meningkatkan hubungan baik dengan jajaran dokter pada strategi SO disini adalah dimana perusahaan terus tetap aktif berusaha untuk menjalin hubungan pada sasaran utama pemasaran produk prospan, yaitu dokter ahli anak dan paru. Karena tujuan utama perusahaan disini dalam memasarkan obat batuk berbahan herbal adalah dokter ahli anak dan paru, dari dokter ahli anak dan paru ini lah perusahaan berharap besar produk prospan dapat terjual dengan baik. Didalam meningkatkan hubungan tersebut dilakukan pendekatan pada dokter anak dan dokter paru, dengan melakukan kegiatan melalui sesi ilmiah seperti: symposium, product presentasion, dan pertemuan para ahli.

\subsection{Analisis Matrik SWOT Untuk Strategi ST}

Mengatasi ancaman dan mempergunakan kekuatan untuk meningkatkan penjualan produk Prospan.

a). Menjelaskan studi ilmiah prospan ke dokter ahli anak.

Menjelakan studi ilmiah produk Prospan ke dokter ahli anak dimaksudkan untuk memberi tahu lebih luas akan produk prospan lebih baik dibanding kompotitor terutama mekanisme kerjanya, sebagai aksi ganda dalam mengatasi batuk, sekretolitik (proses pengenceran lender/dahak) dan bronkodilator (melebarkan saluran nafas).

\section{b). Menjelakan secara ilmiah kelebihan prospan}

Strategi disini perusahaan harus menjelaskan lebih detail akan kandungan bahan baku prospan yaitu bahan herbal, dimana didalam kandungan herbal itu lebih aman dalam hal efek samping dibanding obat-obat batuk yang mengandung bahan baku kimia.

\subsection{Analisis Matrik SWOT Untuk Strategi WO}

Meminimalkan kelemahan produk dengan memanfaatkan peluang pasar untuk me- ningkatkan volume penjualan.

1. Sasaran promosi lebih diutamakan kepada jajaran dokter ahli anak. Karena batuk rentan menyerang anak-anak dan produk Prospan hanya memiliki kemasan botol syrup saja oleh karena itu strategi yang tepat adalah perusahan menargetkan prospan untuk ditujukan kepada dokter ahli anak, selain aman dan kemasan syrup berbahan herbal produk Prospan juga tidak memberikan efek samping yang aman buat anak-anak serta tidak hanya dibatasi untuk anak-anak saja akan tetapi juga dapat untuk dikonsumsi untuk orang dewasa.

2. Mempertahankan harga agar tidak lebih mahal dibanding dengan harga obat-obat kimia. Strategi mempertahankan harga disini berorientasi studi klinis yang dilakukan, ba-han baku utama, tingkat keamanan yang tinggi serta berorientasi pada stabilitas, hal ini dilakukan untuk mempertahankan hubungan yang stabil perusahaan dengan perusahaan pesaing agar dapat meningkatkan volume penjualan.

3. Meyakinkan para dokter (anak \& paru) akan produk prospan.

Pada strategi disini perusahaan harus aktif melalui medical refresentatif (medref) berusaha untuk meyakinkan para dokter bahwa efektifitas prospan sama dengan obatobat berbahan kimia lainnya, dimana dapat diketahui dan dilihat berdasarkan studi klinis yang ada.

\subsection{Analisis Matrik SWOT Untuk Strategi WT}

Meminimalkan kelemahan dan menghindari ancaman yang bertujuan untuk menghindari dampak negatif penjualan. demikian pula mengimbangi agresifitas promosi dari pesaing yakni melakukan promosi sangat penting untuk meningkatkan strategi pemasaran dalam perusahaan. Promosi adalah suatu bentuk komunikasi untuk memberikan informasi. Disini perusahaan harus aktif berusaha untuk mengimbangi agresifitas promosi dari perusahaan pesaing, dengan selalu ikut melakukan symposium, pameran dll., serta dengan menonjolkan kelebihan produk Prospan dibandikan kompetitornya, dimana 
produk Prospan memiliki kandungan aktif herbal dan aksi gandanya.

\section{KESIMPULAN DAN SARAN \\ 6.1 Kesimpulan}

Berdasarkan hasil penelitian dan pengolahan oleh PT. SOHO Global Health maka diperoleh kesimpulan sebagai berikut:

1. Berdasarkan dari uji validitas diperoleh faktor-faktor yang mempengaruhi kesuksesan PT. SOHO Global Health dilihat dari faktor-faktor internal kekuatan, produk yang mengandung bahan aktif ektrak herbal daun ivy, didukung banyak studi klinis, dan citra perusahaan yang baik didalam memasarkan obat-obat berbahan herbal. Faktor internal kelemahan adalah tidak adanya kemasan tablet/bentuk kapsul, harga yang relatif premium dan keyakinan dokter akan obat-obat alami (herbal) masih lemah. Faktor eksternal peluang adalah pasar (konsumen) mulai aktif mencari obat-obatan yang aman yang berbahan dasar herbal dan belum banyaknya beredar obat herbal dengan reputasi farmasi. Faktor eksternal ancaman adalah kegiatan promosi yang aktif dari pesaing (kompetitor) dan obat-obat ekpektoran berbahan kimia sudah banyak tersedia di Indonesia.

2. Kendala yang dihadapi dalam strategi pemasaran obat batuk Propsan pada PT. SOHO Global Health yaitu: a). Kemampuan man power dan financial; b). Perusahaan belum dekat dengan target dokter.; c). Kemasan pada obat batuk prospan hanya bentuk cair didalam botol, belum adanya kemasan tablet atau bentuk kapsul; d). Harga yang ditawarkan untuk obat batuk berbahan herbal relative premium; e) Keyakinan dokter akan obatobatan berbahan alami (herbal) masih lemah.

3. Berdasarkan analisis matrik SWOT tersebut diperoleh nilai $\mathrm{SO}=3.85, \mathrm{ST}=$ 3.85 , $\mathrm{WO}=3,54$ dan $\mathrm{WT}=3,54$ dan diperoleh gambaran melalui diagram analisis SWOT bahwa posisi PT. SOHO Global Health berada pada kuadran I, yang menyatakan bahwa PT. SOHO Global Health berada pada tahap Growth. Dimana faktor eksternal PT. SOHO
Global Health memiliki peluang dan ancaman yang cukup seimbang dan dilihat dari faktor internal kelemahan yang lebih rendah dari kekuatan sehingga perusahaan dapat tumbuh berkembang dengan baik dan dapat memasarkan produk Prospan tersebut dipasaran obat ekpektoran di Indonesia. Sedangkan berdasarkan hasil analisis matrik kombinasi SWOT maka didapat alternatif pilihan strategi yang yang dapat dipilih diantaranya adalah:

a. Strategi Strengths-Opportunity: menjaga kualitas produk, meningkatkan mutu produk, dan meningkatkan hubungan baik dengan jajaran dokter;

b. Strategi Strengths-Treaths: menjelaskan studi ilmiah prospan ke dokter ahli anak, dan menjelakan secara ilmiah kelebihan prospan;

c. Strategi Weakness-Opprtunity: sasaran promosi lebih diutamakan kepada jajaran dokter ahli anak, mempertahankan harga agar tidak lebih mahal dibanding dengan harga obatobat kimia, dan Meyakinkan para dokter (anak dan paru) akan produk Prospan.

d. Strategi Weakness-Treaths: mengimbangi agresifitas promosi dari pesaing.

\subsection{Saran}

Berdasarkan hasil yang diperoleh dari penelitian, maka penulis memberikan saran kepada perusahaan dalam upaya menentukan kebijakan demi perkembangan produk Prospan dari PT. SOHO Global Health. Adapun untuk saran yang diberikan adalah sebagai berikut:

1. Diharapkan PT. SOHO Global Health untuk membuat kemasan baru pada produk obat batuk berbahan herbal (prospan) yaitu dalam bentuk tablet/bentuk kapsul untuk menjangkau segmen pasar baru dan meningkatkan volume penjualannya.

2. Dengan melihat kemampuan ekonomi masyarakat saat ini harga yang relatif premium dari Prospan secara tidak langsung membuat produk tersebut kian sulit 
untuk dipasarkan, dan adanya persaingan dari perusahaaan kompetitor yang mengakibatkan masyarakat untuk berpikir ulang untuk membeli obat-obat, karena daya beli masyarakat untuk membeli obat tersebut kiat sulit maka disarankan perusahaan untuk menurunkan harga produk tersebut, agar lebih mudah dipasarkan dan diterima para konsumen.

\section{DAFTAR PUSTAKA}

Buku:

Abdullah Thamrin dan Tantri Francis. 2012. Manejeman Pemasaran. Penerbit: PT. Raja Grafindo Persada.

Arikunto Suharsimi. 2013. Prosedur Penelitian: Suatu Pendekatan Praktik. Penerbit: Rineka Cipta, Jakarta.

Assauri Sofjan. 2013. Strategic Management: Sustainable Competitive Advantages. Penerbit: PT. Rajagrafindo Persada, Depok.

Herlambang Susatyo. 2013. Pengantar Manajemen: Cara Mudah Memahami Ilmu Manjemen. Penerbit: Goysen Publishing, Yogyakarta.

Kotler Philip. 2008. Manjeman Pemasaran, Edisi 13, Jilid 1. Penerbit: Erlangga, Jakarta.

Rangkuti Freddy. 2013. Riset Pemasaran. Penerbit: PT. Gramedia Pustaka Utama, Jakarta.

Rangkuti Freddy. 2014. Analisisi SWOT: Cara Perhitungan Bobot, Rating dan OCAI. Penerbit: PT. Gramedia Pustaka Utama, Jakarta.

Sawarno Jonathan. 2013. Strategi Melakukan Riset: Kuntitatif, Kualitatif, Gabungan. Penerbit: C.V ANDI OFFSET, Yogyakarta.

Sunyoto Danang. 2013. Manajemen Pemasaran (Pendekatan Konsep, Kasus, dan Psikologi Bisnis). Penerbit: PT. BUKU SERU, Jakarta.
Suryana Yaya dan Najib Mohammad. 2015. Metode Penelitian Manajemen Pendidikan. Penerbit: Pustaka Setia, Bandung

Suryatama Erwin. 2014. Lebih Memahami Analisisi SWOT Dalam Berbisnis. Penerbit: Kata Pena, Surabaya.

Suwarno Jonathan. 2006. Analisis Data Penelitian Menggunakan SPSS. Penerbit: C.V ANDI OFFSET,Yogyakarta.

Syukron Amin. 2013. Pengantar Manajemen Industri. Penerbit: Graha Ilmu, Yogyakarta.

\section{Jurnal:}

Christianto. P \& Indriyani. R. Jurnal Agora Volume 2 Nomer 2 Tahun 2014. Analisis Strategi Bersaing Pada CV.Tanaya Fiberglass. Program Manjeman Bisnis, Program Studi Manajemen, Universitas Kristen Petra.

Guyana. J \& Mustamu R.H. Jurnal Agora Volume 1 Nomer 3 Tahun 2013. Perumusan Strategi Bersaing Perusahaan Yang Bergerak Dalam Industri Pelayaran. Program Manjeman Bisnis, Program Studi Manajemen, Universitas Kristen Petra (2013).

Legrisca. M. Jurnal Agrotekbis, Volume 1 No.3 ISSN 2338-3011. Perkembangan Strategi Pemasaran Abon Ikan Ukm Sri Rejeki: Pendekatan Marketing Mix. Mahasiswa, Jurusan Argobisnis Fakultas Pertanian Universitas Tadulako, Palu.

Nazaruddin. R. Manajemen IKM September 2011 (125-132), Volume 6 No.2 ISSN 2085-8418. Analisis Strategi Pemasaran Peternakan Ayam CV. Intan Jaya Abadi (Ija) Sukabumi. Departeman Manajemen, Fakultas Ekonomi dan Manajemen Institut Pertanian Bogor, Bogor.

Nugrohojati. A.S. Skripsi Teknik Industri. 2013. Perancangan Strategi Pemasaran Melalui Metode Swot Guna Meningkatkan Volume Penjualan (Studi Kasus: Pt.Ci Kemang Jakarta Selatan). Fakultas Teknik Matematika dan Ilmu Pengeta- 
huan Alam, Universitas Indraprasta PGRI, Jakarta.

Wulandari. W.W. Jurnal Agribisnis ISSN 2302-1713. 2012. Strategi Pemasaran Susu Kaleyo di Umkm Brayat Manunggal Kabupaten Sragen. Studi Program Agribisnis, Fakultas Pertanian, Universitas Sebelas Maret, Surakarta
Website:

Lillytaa.blogspot.com/2013/05 Konseppemasaran-farmasi.htm

https://ahmadfiki.wordpress.com/2013/12/07/ societal-marketing-farmasi/ 